\title{
APLIKASI WEB PENJUALAN QUBAH STAINLESS STEEL DI MAHKOTA BAROKAH MENGGUNAKAN PEMOGRAMAN PHP
}

\author{
Winda Persolita ${ }^{1}$, Fauzansyah $^{2}$, Reza Fahlevie F. Afidh $^{3}$, Elisawati $^{4}$ \\ ${ }^{1,2,3}$ Sekolah Tinggi Managemen Informatika dan Komputer (STMIK) DUMAI \\ Jalan Utama Karya Bukit Batrem Dumai-Riau kode pos 28826 \\ e-mail : windapersolita ${ }^{1} @$ gmail.com
}

\begin{abstract}
ABSTRAK
Qubah merupakan arsitektur dari sebuah masjid yang berbentuk bulat penuh, setengah bola, putar dan berwarna. Telah dilakukan penelitian pada cabang Mahkota Barokah Dumai, dimana permasalahan yang mendasar terletak pada penjualan qubah mesjid di kota Dumai yang masih dilakukan secara konvensional, sedangkan informasi tentang penjualan qubah masih diketahui dari masyarakat setempat yang menyebabkan kurangnya pemasaran qubah mesjid di kota dumai.. Selain itu pendataan tentang penjualan qubah masih dicatat secara manual sehingga belum ada pendataan data customer yang pernah membeli qubah. Oleh karena itu dirancanglah sebuah aplikasi web secara online dengan menggunakan sistem penyimpanan data yang terstruktur yaitu database MySQL dan bahasa pemograman PHP, dengan adanya sistem ini transaksi penjualan qubah di kota dumai dapat dilakukan dimanapun dan kapanpun sehingga memudahkan pendataan penjualan.
\end{abstract}

Kata kunci :Web, Penjualan, Qubah, PHP.

\section{PENDAHULUAN}

Qubah atau sering disebut kepala mesjid. Bagi masyarakat muslim, kepala mesjid merupakan simbol keberadaan umat muslim. Fakta tersebut menjadikan kebutuhan kepala mesjid menjadi perhatian.Salah satunya oleh PT.Mahkota Barokah, perusahaan yang bergerak dibidang pembuatan arsitektur kepala mesjid.

Dengan melihat suatu peluang bisnis, PT.Mahkota Barokah memasarkan qubah mesjid di hampir seluruh wilayah Indonesia salah satunya memiliki cabang di kota dumai. Sejak lama penjualan qubah mesjid di kota dumai masih dilakukan secara konvensional sehingga pembeli harus datang langsung ketempat penjualan qubah, sedangkan informasi tentang penjualan qubah masih diketahui dari masyarakat setempat. Selain itu data tentang penjualan qubah seperti data qubah, data penjualan dan data customer masih dicatat secara manual sehingga belum ada pendataan data customer yang pernah membeli qubah.Dilihat dari hal ini tentu saja dapat menyebabkan kurangnya pemasaran qubah mesjid dikota dumai.
Dari uraian diatas tentu diperlukan suatu sistem yang dapat membantu dalam penjualan qubah agar lebih mudah dengan menggunakan pemograman PHP yang memiliki keunggulan dalam pembuatan website yang dinamis. Website dinamis itu sendiri merupakan website yang source kodenya dapat diubah- ubah dan dapat diperbarui sehingga mudah didistribusikan dengan bebas kedalam aplikasi yang akan digunakan sehingga sesuai dengan yang diharapkan pengguna.

Adapun tujuan dari penelitian ini adalah : Untuk membangun sebuah sistem informasi secara online yang dapat membantu dalam penjualan qubah mesjid di kota dumai.Untuk menyediakan sistem web penjualan yang dapat menyimpan data secara akurat. Untuk membangun sebuah sistem web penjualan qubah mesjid menggunakan bahasa pemograman PHP.

\section{a. Aplikasi}

Secara istilah aplikasi adalah suatu program yang siap untuk digunakan yang dibuat untuk melaksanankan suatu fungsi bagi pengguna jasa aplikasi serta penggunaan aplikasi lain yang dapat digunakan oleh suatu 
IN F O R M A I I A

Jurnal Informatika, Manajemen dan Komputer, Vol. 10 No. 1, MEl 2018

elSSN : 2580-3042

pISSN : 1979-0694

sasaran yang akan dituju.(Juansyah, 2015)

\section{b. Web}

Website adalah merupakan kumpulan halaman yang menampilkan infromasi data, baik yang bersifat statis maupun yang bersifat dinamis yang membentuk suatu rangkain yang saling terkait dengan jaringan-jaringan halaman (hyperlink) lainnya.Untk mengakses website tersebut harus mengunakan perangkat lunak (sofware) yang disebut browser.(Dahlan, 2013:1)

Jadi, Web merupakan kumpulan halaman yang dapat menampilkan data- data statis maupun dinamis menggunakan browser untuk membuka website.

\section{c. Penjualan}

Penjualan adalah suatu kegiatan pokok perusahaan untuk memperjual- belikan barang dan jasa yang perusahaan hasilkan. Sehingga dalam kegiatan sistem penjualan dilakukan dengan berbagai cara untuk memudahkan kegiatan jual- beli.(Sujarweni, 2015:79)

Konsep dasar penjualan di mana Perusahaan yang yang berorientasi pada selling concept percaya bahwa konsumen tidak akan membeli produk kecuali produk itu dijual dalam skala penjualan yang besar dan usaha promosi yang gencar. Penjualan agresif semacam ini menitikberatkan pada penciptaan transaksi penjualan, bukan pembangunan hubungan pelanggan jangka panjang yang menguntungkan. Tujuannya sering berkisar pada cara menjual produk/jasa yang dihasilkan perusahaan dan bukan membuat produk/jasa yang dibutuhkan pasar. Konsep ini berasumsi konsumen akan Terbujuk Oleh Iklan Atau Cara penjual untuk membeli produk dan menyukainya. Bila tidak suka, konsumen diharapkan melupakan kekecawaan mereka dan membelinya lagi nanti.

Dalam sistem penjualan terdapat dua macam, yaitu sistem penjualan tunai dan sistem penjualan kredit :

1. Sistem penjualan tunai merupakan sistem yang diberlakukan oleh perusahaan dalam menjual barang dengan cara mewajibkan pembeli untuk melakukan pembayaran harga terlebih dahulu sebelum barang di serahkan pada pembeli. Setelah pembeli melakukan pembayaran, baru barang diserahkan, kemudian transaksi penjualan dicatat.

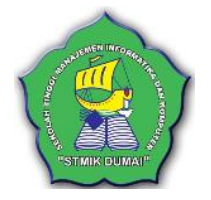

2. Sistem penjualan kredit merupakan sistem penjualan dimana pembayarannya dilakukan setelah barang diterima pembeli. Jumlah dan jatuh tempo pembayarannya disepakati oleh kedua pihak.

Berikut merupakan beberapa Prosedur Penjualan Tunai:

a. Prosedur order penjualan. Dalam prosedur ini, bagian penjualan menerima order dari pembeli dan membuat faktur penjualan tunai. Setelah pembeli membayar, bagian gudang mengirimkan barang kepada pembeli.

b. Prosedur penerimaan kas. Dalam prosedur ini, bagian kasa menerima pembayaran dari pembeli dan memberikan tanda pembayaran (berupa pitaregister kas dan cap "Lunas" pada faktur penjualan tunai), kemudianpembeli mengambil barang.

c. Prosedur pembungkusan dan penyerahan barang. Dalam prosedur ini pengiriman hanya menyerahkan barang kepada pembeli.

d. Prosedur pencatatan penjualan tunai. Dalam prosedur ini, bagian akuntansi melakukan pencatatan transaksi penjualan tunai.

Dapat disimpulkan bahwa Penjualan adalah suatu kegiatan pokok perusahaan untuk memperjual- belikan barang dan jasa sesuai prosedur penjualan dengan pembayaran tunai maupun kredit sehingga kegiatan sistem penjualan dapat terjadi secara sistematis.

\section{d. PHP (Hypertext Preprocessor)}

PHP (Hypertext Preprocessor) merupakan sebuah bahasa scripting yang terpasang pada HTML untuk membuat webside, yang dinamis. PHP ini bersifat open source sehingga source code-nya dapat diubah- ubah dan dapat didistribusikan dengan bebas.(Dahlan, 2013:83)

\section{e. MySQL}

MySQL adalah database server, database yang dibuat di MySQL dapat kita akses dalam komputer jaringan, baik untuk aplikasi single user maupun aplikasi multi user. Dengan menggunakan database $M y S Q L$ dengan memisahkan databasenya menjadi terpusat, sehingga program aplikasinya dapat diinstal pada computer lain yang bertindak sebagai client.(Nugroho, 2014:15) 
I N F ORM A T I K

Jurnal Informatika, Manajemen dan Komputer, Vol. 10 No. 1, MEl 2018

eISSN : 2580-3042

pISSN : 1979-0694

\section{METODOLOGI PENELITIAN}

Untuk mendapatkan hasil penelitian yang benar, diperlukan data dan informasi yang objektif. Metode penelitian ini diuraikan dalam tahapan- tahapan kerangka kerja sebagai berikut:

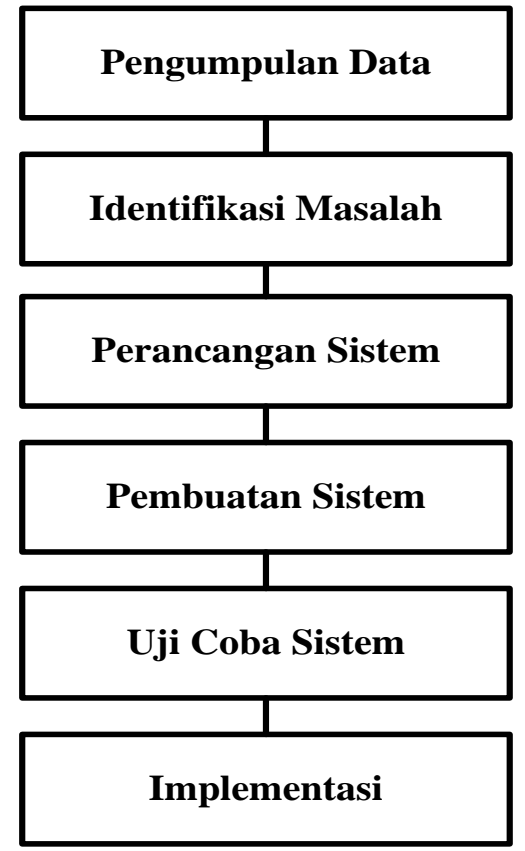

Gambar 1. Kerangka Kerja Penelitian

Berikut merupakan rincian tahapan- tahapan yang dilakukan dalam penelitian ini, yaitu:

1. Pengumpulan Data

Tahap pertama yang dilakukan adalah pengumpulan data dengan teknik Wawancara, Observasi dan Studi Literatur.

a. Teknik wawancara digunakan dalam pengumpulan data untuk mendapatkan jawaban pertanyaan dari pihak tempat usaha qubah.

b. Observasi untuk pengumpulan data dengan mengadakan pengamatan terhadap sistem kerja dari permasalahan yang diteliti.

c. Studi Literatur digunakan melakukan pencarian terhadap berbagai sumber tertulis, baik berupa buku-buku, arsip, majalah, artikel, dan jurnal, atau dokumendokumen yang relevan dengan permasalahan yang dikaji

2. Identifikasi Masalah

Tahapan selanjutnya untuk membuat sistem pengolah data dari penjualan yang harus dilakukan adalah dengan mengetahui masalahmasalah apa yang sedang dihadapi oleh tempat penelitian.

3. Perancangan Sistem
Merancang sistem yang dibutuhkan dalam membangun sistem pengolahan data penjualan dengan memperhitungkan desain system input, output dan database yang akan dibuat untuk memenuhi kebutuhan sistem.

4. Pembuatan Sistem

Pada tahap ini dilakukan pembuatan sistem dari perancangan system yang telah dilakukan untuk membangun sistem perangkat lunak dengan pemograman PHP.

5. Uji Coba Sistem Menggunakan Pemograman PHP

Tahapan selanjutnya adalah pengujian program dengan menjalankan program yang telah dirancang menggunakan pemograman PHP.

6. Implementasi

Pada tahap ini dilakukan pengimplementasian sistem untuk mendapatkan hasil yang sesuai dengan yang diharapkan.

\section{HASIL DAN PEMBAHASAN \\ a. AnalisaSistem Informasi yang sedang Berjalan}

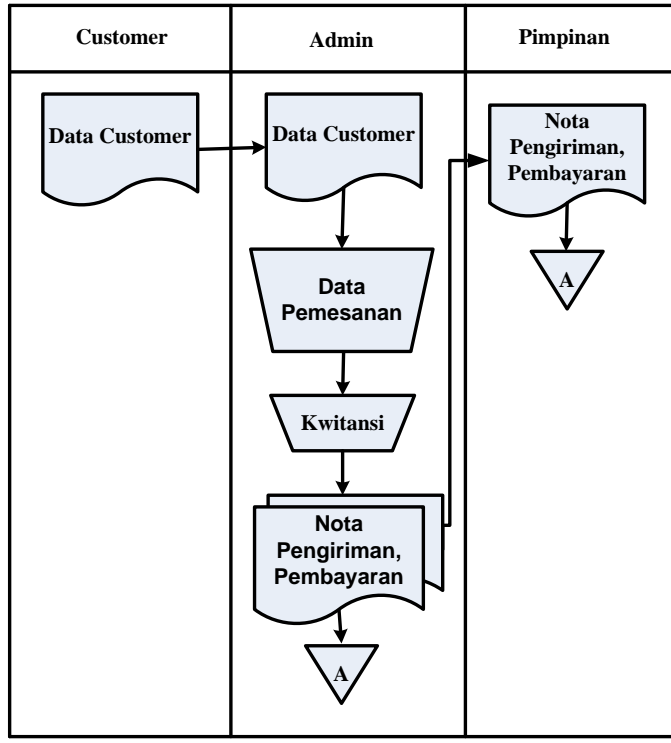

Gambar 2. Aliran Sistem Informasi Lama

Berikut ini merupakan keterangan dari gambar 2. Aliran Sistem Informasi yang sedang berjalan pada tempat penjualan qubah di Mahkota Barokah adalah:

1. Sebelumnya customer memberikan data customer dan data pemesanan kepada penjual Qubah.

2. Selanjutnya penjual membuatkan kwitansi bukti pembayaran sesuai jumlah nominal. 
I N F O R M A T I K A

Jurnal Informatika, Manajemen dan Komputer, Vol. 10 No. 1, MEl 2018

eISSN : 2580-3042

pISSN : 1979-0694

3. Dari transaksi yang terjadi dihasilkan beberapa laporan dalam bentuk tertulis yang akan diberikan kepada pimpinan.

\section{b. Aliran Sistem Informasi Baru}

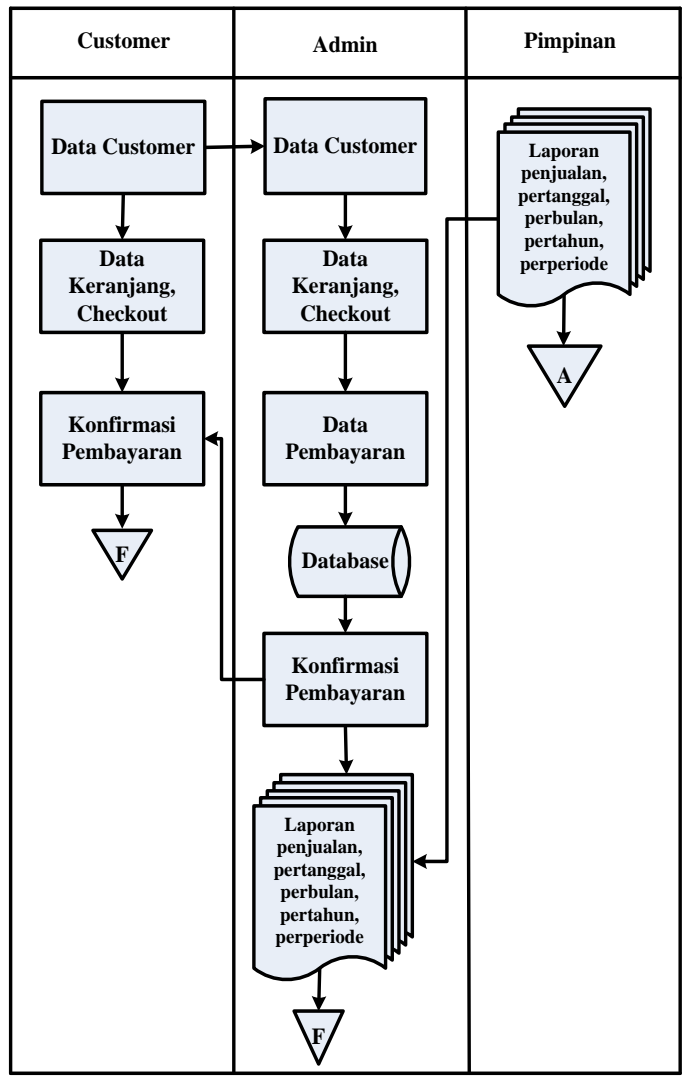

Gambar 3. Aliran Sistem Informasi Baru

Berikut ini merupakan keterangan dari gambar 3. Aliran Sistem Informasi Baru pada aplikasi web penjualan qubah di Mahkota Barokah adalah:

1. Setelah masuk kedalam aplikasi, user bisa langsung melihat daftar qubah melalui halaman utama yang disediakan oleh aplikasi.

2. Setelah itu user harus melakukan registrasi terlebih dahulu sebelum melakukan pemesanan, lalu user masuk menggunakan menu login yang terlah didaftarkan, barulah user bisa langsung melakukan pemesanan dengan mengakses menu home kemudian memilih satu atau beberapa jenis qubah yang ada di halaman utama.

3. Setelah memilih satu atau beberapa jenis qubah yang ada di halaman utama maka aplikasi akan memberikan hasil pemesanan

kepada user melalui menu keranjang.User dapat melihat kembali daftar qubah yang telah di pesan lalu melakukan checkout.

4. Lalu user harus melakukan pembayaran sesuai nominal yang tertera pada aplikasi melalui bank dan konfirmasi dilakukan setelah qubah sampai di alamat user. Sebelum melakukan pembayaran atas pemesanan qubah atau dikonfirmasi oleh admin maka user belum dapat memesan kembali.

5. Di aplikasi ini admin dapat mengakses seluruh halaman aplikasi yang bertujuan untuk melihat kondisi aplikasi apakah ada yang perlu diperbaiki dan diperbarui.

6. Sebelum admin melakukan mengelola data yang tersimpan didalam aplikasi, terlebih dahulu admin melakukan login admin dengan cara mengakses halaman login admin, setelah masuk kehalaman admin kemudian admin melakukan input, ubah, hapus data yang disimpan di aplikasi, admin juga dapat melihat informasi pemesanan dari hasil pemesananuserdan mengkonfirmasikan juga qubah yang telah di terima oleh user.

7. Barulah user dapat melakukan pemesanan kembali.

\section{c. Analisa Kebutuhan Sistem}

Aplikasi web penjualan qubah di Mahkota Barokah merupakan aplikasi yang digunakan untuk mengelola data penjualan qubah. Data penjualan qubah ini meliputi pengelolaan input, proses dan output. Input berupa data qubah, data kategori, data customer, dengan proses transaksi pemesanan, dan pembayaran qubah. Sedangkan output yang diharapkan dapat memberikan informasi kepada customer, admin dan pimpinan yaitu konfirmasi pembelian, laporan penjualan, laporan pertanggal, laporan perbulan, laporan pertahun dan laporan perperiode.

\section{d. Pemodelan Proses}

Gambaran proses pada sistem baru menggunakan pemodelan terstruktur penjualan qubah dalam bentuk sebagai berikut : 
INFORMA T IKA

Jurnal Informatika, Manajemen dan Komputer, Vol. 10 No. 1, MEl 2018

eISSN : 2580-3042

pISSN : 1979-0694

1. Context Diagram

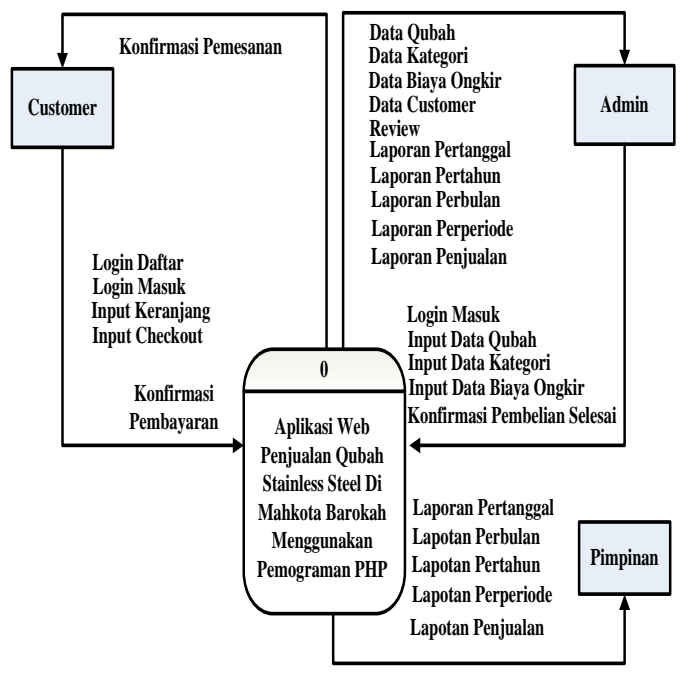

Gambar 4. Context Diagram

2. Data Flow Diagram

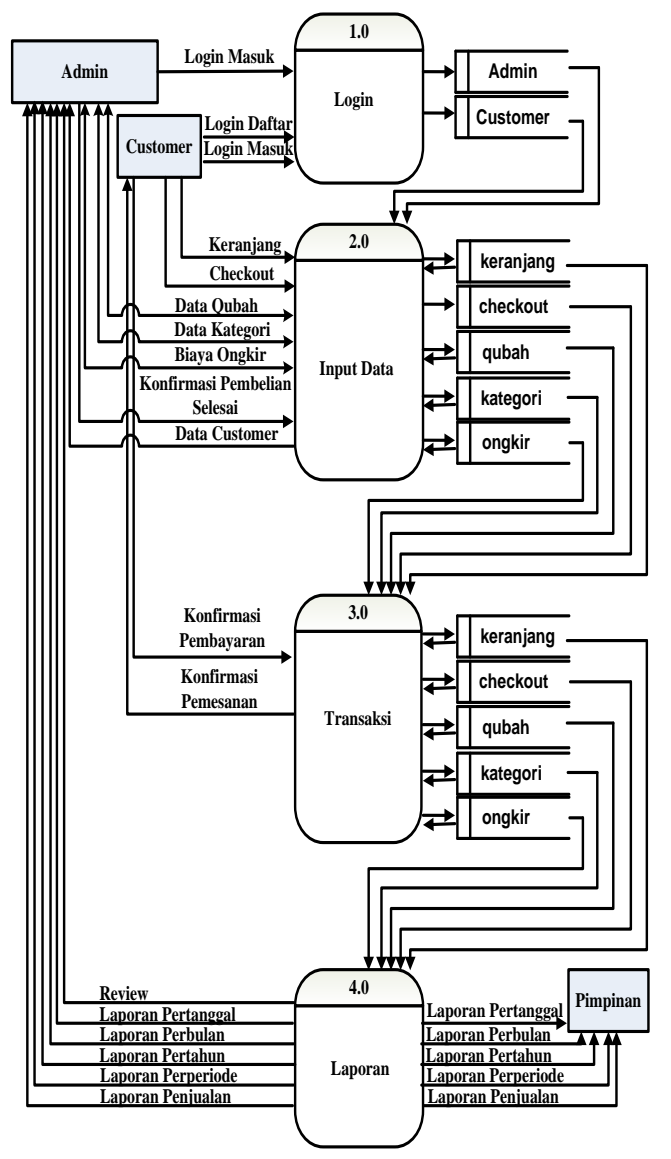

Gambar 5. Data Flow Diagram
3. Entity Relationship Diagram

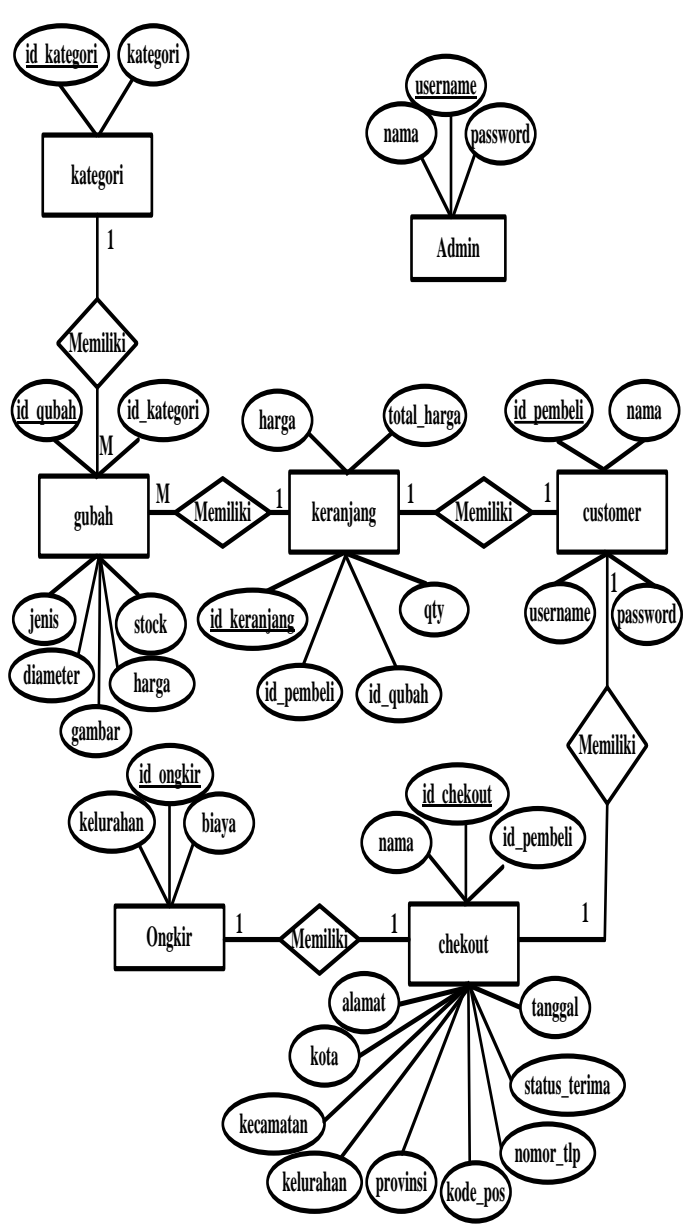

Gambar 6. Entity Relationship Diagram

e. Struktur Program (HIPO)

1. Hipo Menu Utama Pengunjung

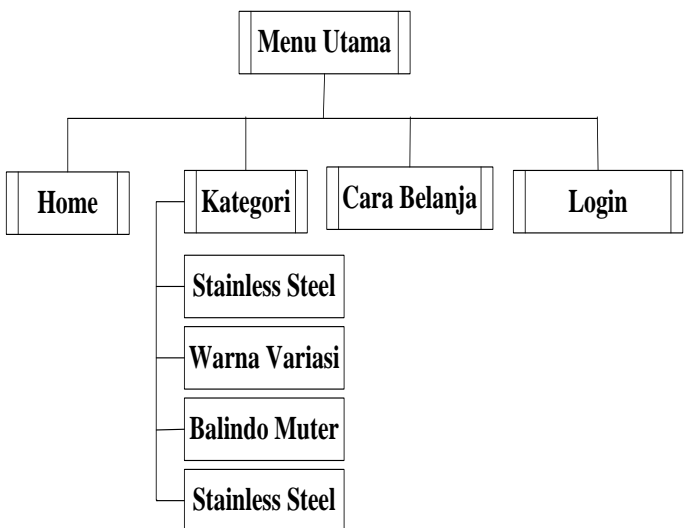

Gambar 7. HIPO Menu Utama Pengunjung 
I N F ORM A T I K

Jurnal Informatika, Manajemen dan Komputer, Vol. 10 No. 1, MEl 2018

eISSN : 2580-3042

pISSN : 1979-0694

2. Hipo Menu Utama Customer

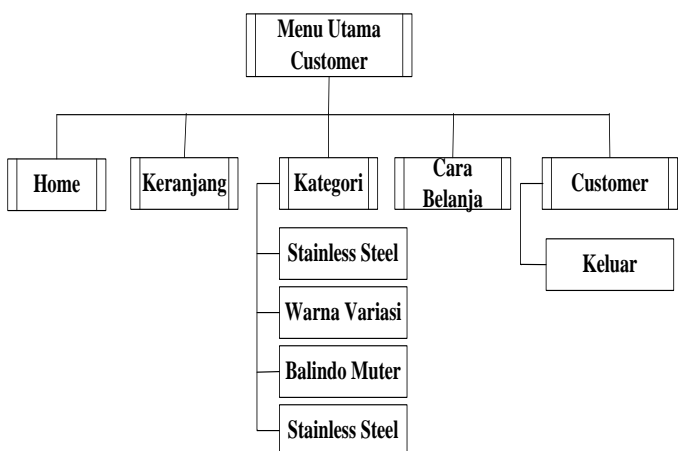

Gambar 8. HIPO Menu Utama Customer

3. Hipo Menu Utama Admin

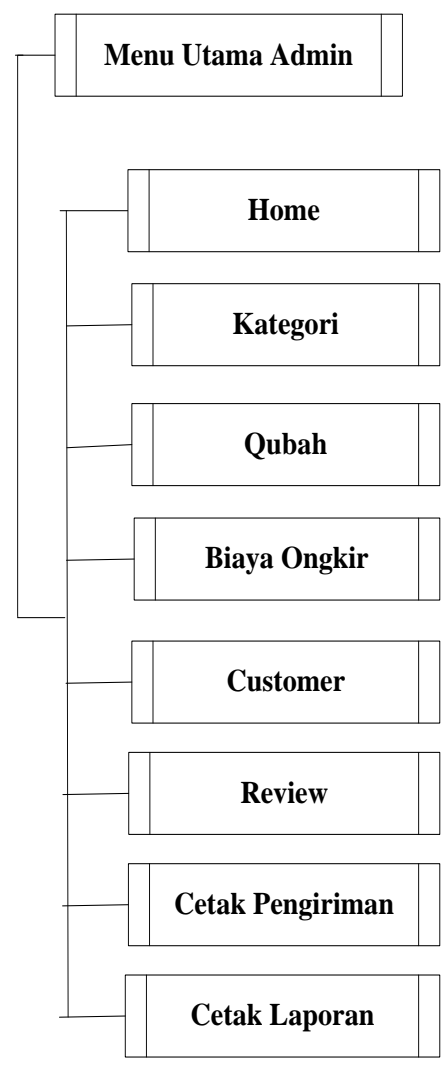

Gambar 9. HIPO Menu Utama Admin

\section{f. Implementasi Program}

1. Halaman Menu Utama

Pada halaman menu utama ini ada beberapa menu yang memiliki fungsi masingmasing.

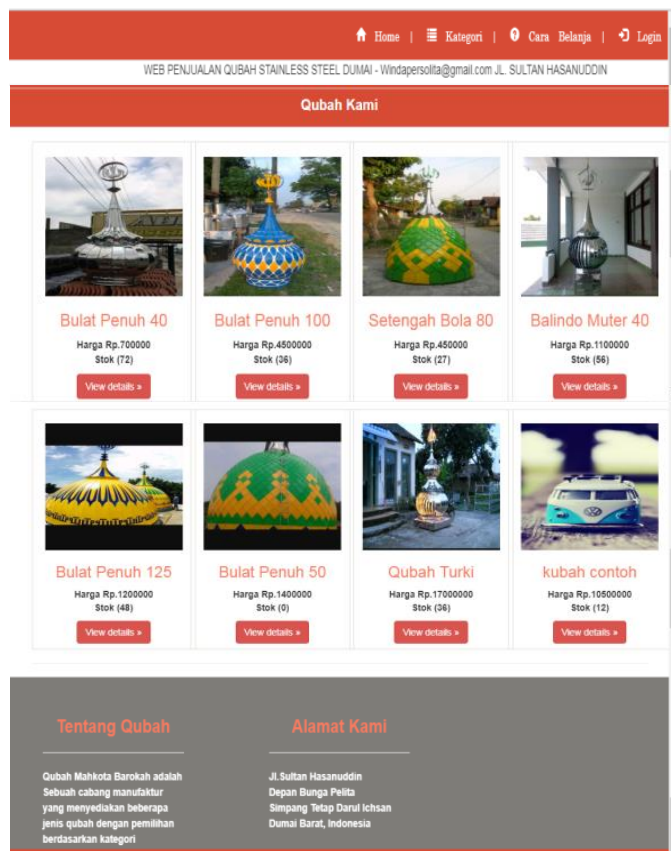

Gambar 10. Halaman Menu Utama

2. Login Customer

Pada form login ini, customer dapat melakukan pemesanan dan pembelian qubah apabila sudah login terlebih dahulu dengan cara mengisi username dan password, setelah itu mengklik tombol Login. Apabila customer belum memiliki username dan password, maka dapat mengklik tombol Daftar untuk melakukan pendaftaran.

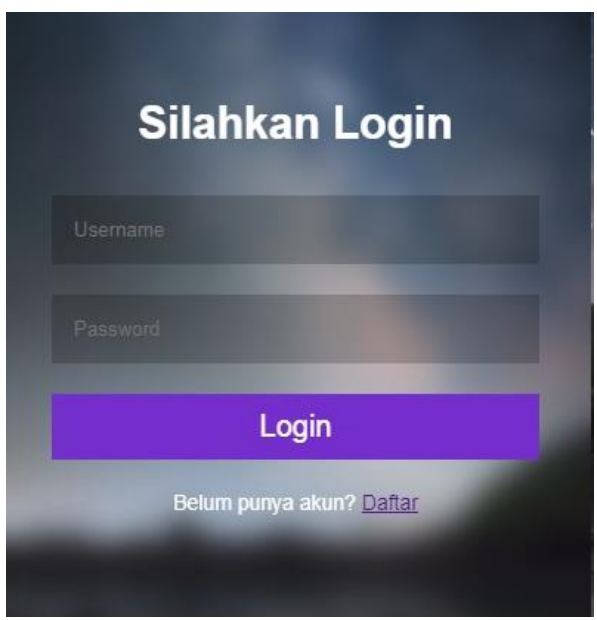

Gambar 11. Login

3. Form Daftar Login

Pada form input daftar login ini, customer dapat mengisi Nama Customer, Username dan Password dari form yang telah disediakan setelah itu dapat menyimpannya dengan 
I N F ORM A T I K

Jurnal Informatika, Manajemen dan Komputer, Vol. 10 No. 1, MEl 2018

eISSN : 2580-3042

pISSN : 1979-0694

mengklik tombol Sign $\boldsymbol{U p}$ kemudian akan ada pesan "anda berhasil mendaftar, silahkan login" klik OK maka sistem akan menampilkan kembaliform login.

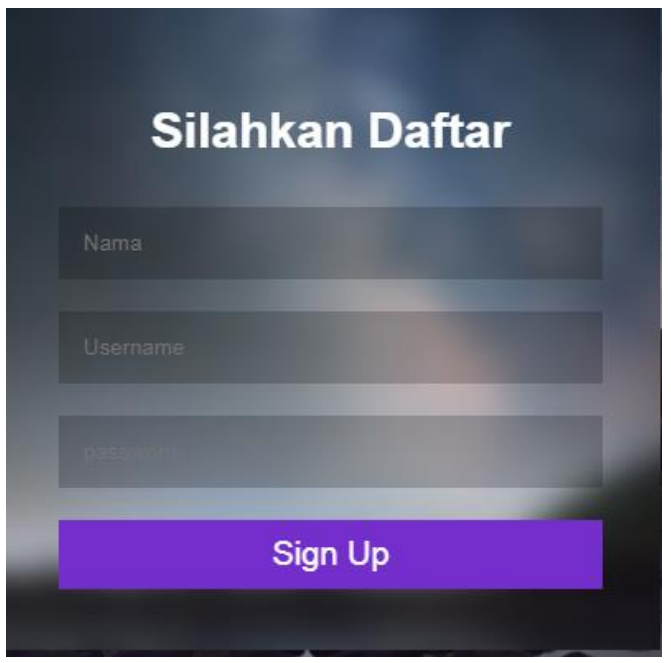

Gambar 12. Daftar Customer

\section{Input Kategori}

Kategori pada menu admin berfungsi menampilkan data kategori, lalu dapat menambahkan kategori klik "+ TAMBAH KATEGORI". Maka akan tampil kolom yang dapat diisi sesuai kategori yang akan ditambahkan lalu klik "Simpan" maka data akan otomatis bertambah. Jika ingin mengubah klik "Edit atau hapus".

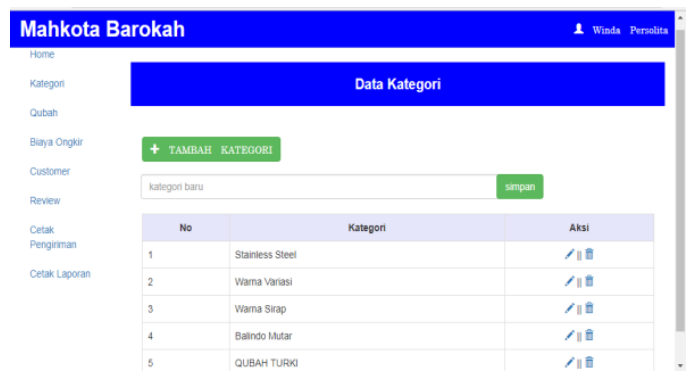

Gambar 13Input Katagori

5. Input Barang

Qubah berfungsi menampilkan data qubah yang telah diinputkan sebelumnya, untuk menambahkan data qubah klik "TAMBAH QUBAH" untuk memperbarui jenis, diameter, berat qubah, gambar, harga qubah, stok klik "Edit atau hapus".Lalu akan muncul Form Tambah Qubah, untuk menambahkan jenis, diameter, berat qubah, gambar, harga qubah dan stok qubah.

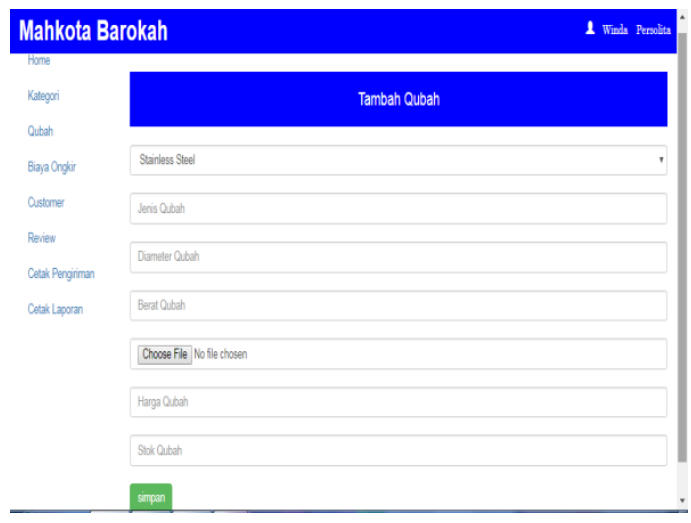

Gambar 14. Input Data Qubah

6. Input ongkir

Biaya Ongkir berfungsi untuk menampilkan daftar biaya ongkos kirim yang di lihat dari kelurahan tujuan pengantaran barang. Ongkir akan ditambahkan jika kelurahan yang dituju belum terdapat di daftar ongkir.

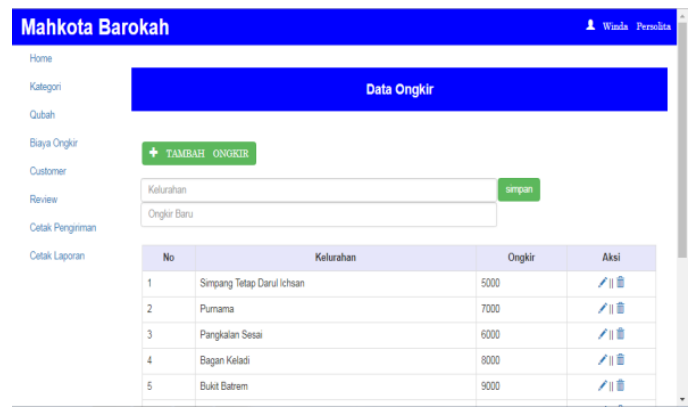

Gambar 15.Input Ongkir

7. Anda dapat melakukan checkout dan mengisi data sesuai tujuan. Jika Anda telah selesai mengisi data maka klik "Selesai".

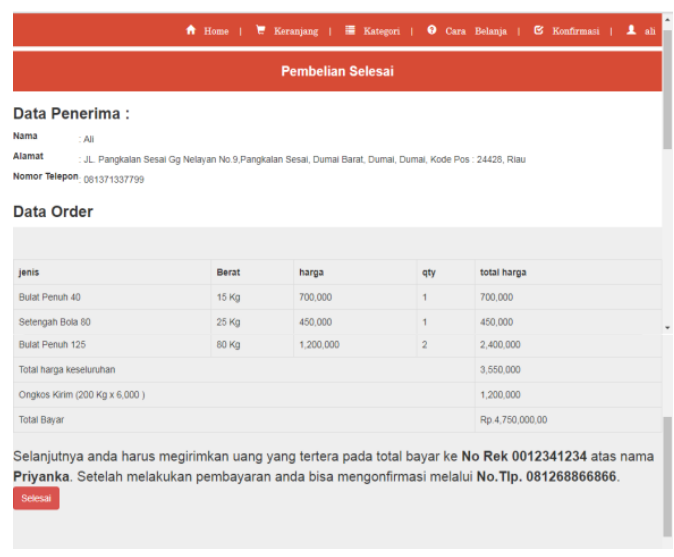

Gambar16. Pembelian Selesai 
I N F O R M A I I A

Jurnal Informatika, Manajemen dan Komputer, Vol. 10 No. 1, MEl 2018

eISSN : 2580-3042

pISSN : 1979-0694

8. Qubah berfungsi menampilkan data qubah yang telah diinputkan sebelumnya, untuk menambahkan data qubah klik "TAMBAH QUBAH" untuk memperbarui jenis, diameter, berat qubah, gambar, harga qubah, stok klik "Edit atau hapus".Lalu akan muncul Form Tambah Qubah, untuk menambahkan jenis, diameter, berat qubah, gambar, harga qubah dan stok qubah.

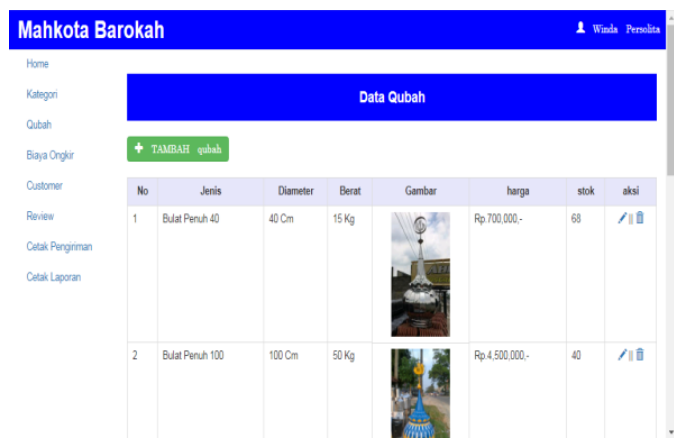

Gambar 17. Data Gubah

9. Review berfungsi untuk menampilkan data pesanan customer, apakah customer telah mangkonfirmasi bahwa barang telah sampai dan admin juga mengkonfirmasi jika qubah yang di pesan telah dikirimkan.

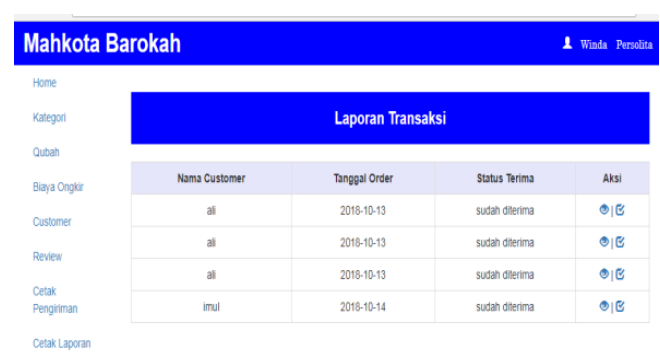

Gambar 18. Review Transaksi

10. Sedangkan simbol mata berfungsi menampilkan detail pembelian qubah yang telah di pesan sebelumnya oleh customer.

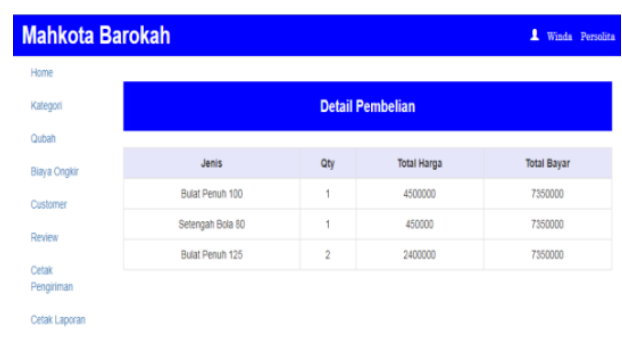

Gambar 19. Detail Pembelian

11. Cetak pengiriman berfungsi untuk menampilkan laporan data pengiriman.

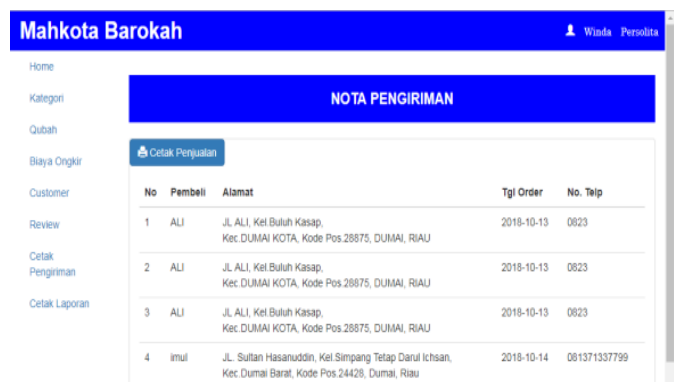

Gambar 20. Cetak Pengiriman

12. Admin dapat mencetak laporan penjualan secara keseluruhan dengan mengklik tombol cetak penjualan yang berada di atas kiri tampilan cetak pengiriman.

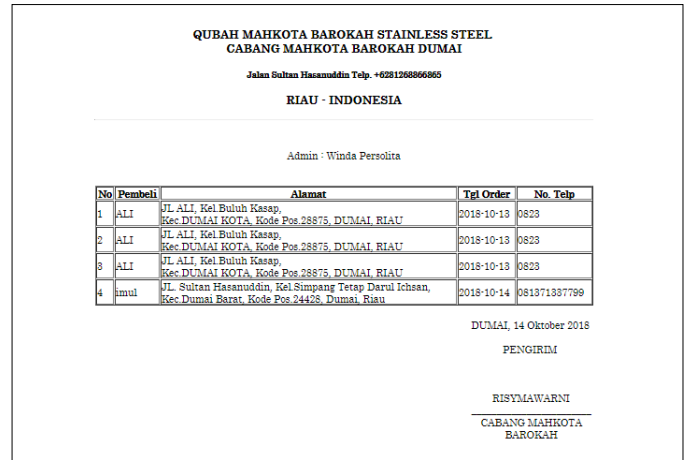

Gambar 21. Laporan Penjualan

13. Cetak Laporan berfungsi untuk menampilkan tombol cetak laporan yang dapat di print untuk laporan kepada pimpinan, cetak laporan terdiri dari cetak laporan pertanggal, cetak laporan perbulan, cetak laporan pertahun serta cetak laporan perperiode tertentu sesuai dengan yang di ingikan

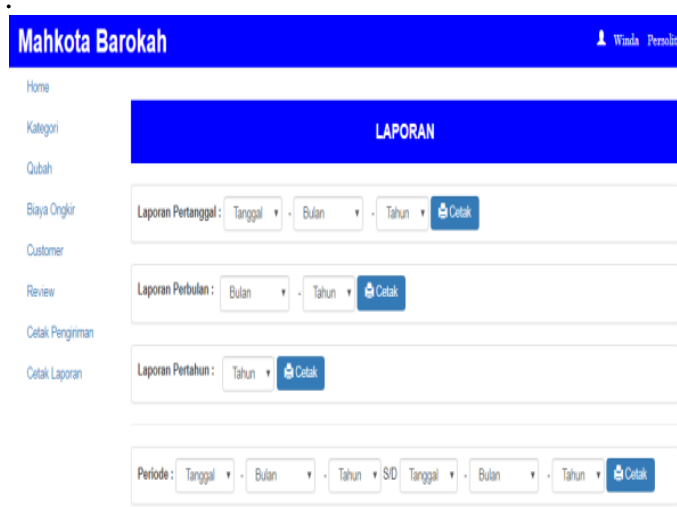

Gambar 22. Cetak Laporan 
I N F O R M A I I A

Jurnal Informatika, Manajemen dan Komputer, Vol. 10 No. 1, MEl 2018

eISSN : 2580-3042

pISSN : 1979-0694

14. Untuk menampilkan laporan pertanggal admin memilih tanggal, bulan serta tahun yang dinginkan, lalu klik tombol cetak yang ada di sebelah kanan, maka akan tampil seperti berikut

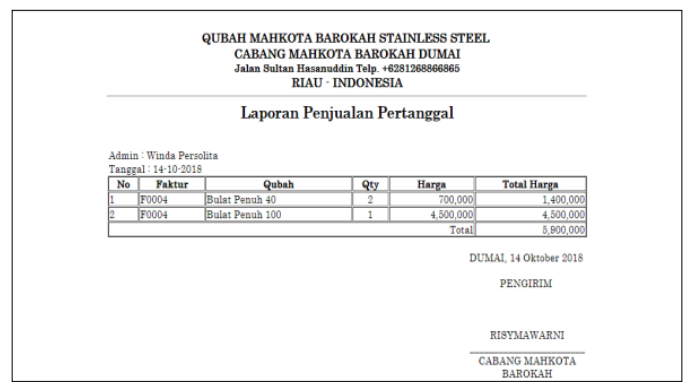

Gambar 23. Laporan Pertanggal

15. Untuk menampilkan laporan perbulan, admin cukup memilih bulan dan tahun yang dinginkan, lalu klik tombol cetak yang ada di sebelah kanan, maka tampil seperti berikut :

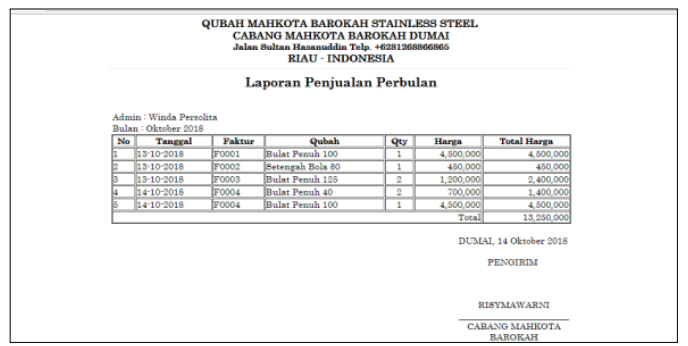

Gambar 24. Laporan Perbulan

16. Untuk menampilkan laporan pertahun, admin hanya memilih tahun yang dinginkan, lalu klik tombol cetak yang ada di sebelah kanan, maka akan tampil seperti berikut :

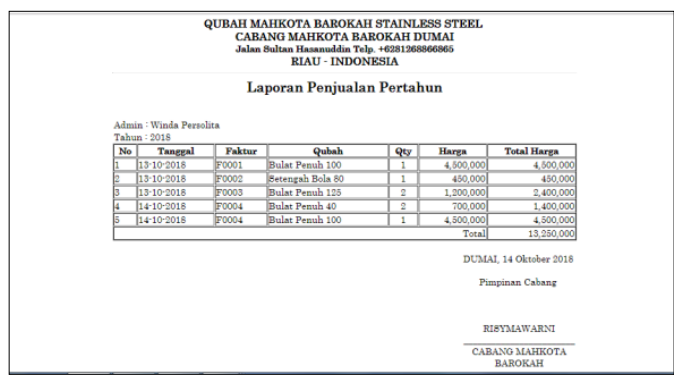

Gambar 25. Laporan Pertahun

17. Untuk menampilkan laporan perperiode, admin harus memilih dari tanggal bulan, tahun sampai dengan tanggal, bulan, tahun yang dinginkan, lalu klik tombol cetak yang ada di sebelah kanan, maka akan tampil seperti berikut

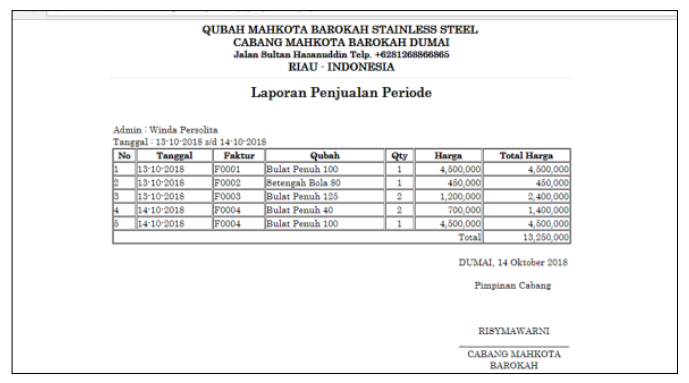

Gambar 26. Laporan Perperiode

\section{KESIMPULAN}

Berdasarkan hasil penelitian dan pengujian yang telah dilakukan, maka dapat dibuat suatu kesimpulan dari hasil analisa pengujian sistem. Diantaranya sebagai berikut :

1. Aplikasi penjualan qubah Mahkota Barokah ini dapat membantu pembeli untuk mengetahui jenis dan harga qubah sebelum membeli.

2. Dalam melakukan pembelian apabila customer sudah mendaftarselanjutnya apabila ingin membeli kembali tidak perlu mendaftar lagi cukup langsung login ke sistem.

3. Daftar qubah yang tersedia dapat dilihat di sistem apabila ingin mengetahui terlebih dahulu adanya qubah yang ingin dibeli sebelum login.

\section{REFERENSI}

Dahlan, M. (2013). Membuat Web PHP. Yogyakarta: Mitra Utama.

Ismael. (2017). Rancang Bangun Sistem Informasi Penyaluran Semen Padang Untuk Daerah Bengkulu Selatan Di Cv. Mutia Bersaudara. Jurnal Edikinformatika, 2, 147-156.

Iswandy, E. (2015). Sistem Penunjang Keputusan Untuk Menentukan Penerimaan Dana Santunan Sosial Anak Nagari Dan Penyalurannya Bagi Mahasiswa Dan Pelajar Kurang Mampu Di Kenagarian Barung - Barung Balantai Timur. Jurnal Teknoif, 3(2), 70-79. Https://Doi.Org/2338-2724

Juansyah, A. (2015). Pembangunan Aplikasi Child Tracker Berbasis Assisted - Global Positioning System ( A-GPS ) Dengan Platform Android Jurnal Ilmiah Komputer Dan Informatika ( KOMPUTA ). Jurnal Ilmiah Komputer Dan Informatika 
IN F O R M A T I A

Jurnal Informatika, Manajemen dan Komputer, Vol. 10 No. 1, MEI 2018

elSSN : 2580-3042

pISSN : 1979-0694

Komputa, 1(1), 1-8.

Kaharu, S., \& Sakina, O. (2016). Perancangan Sistem Informasi Pengolahan Data Akademik Pada Tk Al-Hidayah Lolu. Jurnal Jesik, 2(1), 30-41.

Nugroho, B. (2014). Panduan Membuat Aplikasi Inventory Barang Dengan Visual Basic 6. Jakarta: Pt. Alex Media Komputindo.

Radillah, T., Widodo, P. P., \& Linarta, A. (2017). Aplikasi Optimalisasi Layanan Kunjungan Rutan Klas IIB Dumai Berbasis SMS Outo Response (SAR). Prosiding Seminar Nasional Sekolah Tinggi Teknologi Dumai, 1(1).

Rohayati, A. I. H. (2016). Perancangan Dan Implementasi Sistem Informasi Inventaris Laboratorium, 16(2), 15-19.

Rubiati, N. (2018). Aplikasi Informasi Pelayanan Fitness Pada Golden Fitness Center Dumai Dengan Bahasa Pemograman PHP. Informatika, Jurnal, 10(1), 1-6.

Sovia, R., \& Febio, J. (2011). Membangun Aplikasi E-Library Menggunakan Html, Php Script, Dan Mysql Database. Jurnal Teknologi Informasi \& Pendidikan, 3(1), 86-101.

Sujarweni, V. W. (2015). Sistem Akuntansi. (Mona, Ed.) (Pertama). Yogyakarta: Pustaka Baru Press Yogyakarta.

Zakir, A. (N.D.). Rancang Bangun Responsive Web Layout Dengan Menggunakan Bootstrap Framework, (70), 7-10. 